\title{
224 転位セル構造・亜結晶粒の自己組織化モデルと空間パターニング \\ A Self-Organization Model and Spatial Patterning of Dislocation Cell Structure and Subgrain
}

\author{
○藤本 敦 (慶大[院]), 松下 将明 (慶大[院]), 正 志澤 一之(慶大) \\ Atsushi FUJIMOTO, Graduate School of Keio University \\ Masaaki MATSUSHITA, Graduate School of Keio University \\ Kazuyuki SHIZAWA, Keio University, 3-14-1 Hiyoshi, Kohoku-ku, Yokohama 223-8522
}

Key Words: Dislocation Cell Structure, Subgrain, Self-Organization, SS-Dislocation Density Tensor, Spatial Patterning

\section{1. 精 言}

金属結晶に負荷をかけると，主すべり系に存在する膨大な 数の転位ループと 2 次すべり系の林立転位の相互作用により セル構造とよばれる空間パターンが自己組織化される(図 1(a)). これまでに著者ら ${ }^{(1)}$ が検討してきた PSBs 構造は FCC 単結晶に綝り返し負荷を加えた際にのみ形成されるのに対し， セル構造は FCC 構造, BCC 粠造, 単結晶, 多結晶を問わず, またあらゆる負荷形態において形成されることが知られてい る.よって, PSBs と比較して応用範囲も広く, セル構造の自 己組織化モデルが構築されれば, 種々の金属材料の加工硬化 に応用が可能である.しかし，従来の転位自己組織化モデル の多くは PSBs 形成モデルであり, セル構造の空間パターニ ングについての検討は極めて少ないのが現状である(2)(3).

著者らは前報(4)において, 単結晶の線形硬化段階を表現す る反応-拡散方程式を導出し, セル構造の空間パターニングを 数値解析的に再現した. しかしながら, さらに加工硬化が進 んだ動的回復段階においてセル構造が垔結晶粒へ遷移する過 程(図 1(a)，(b))を表現するには至っていない，そこで本報で は, 上述の反応-拡散方程式に動的回復を表現する項を新たに 導入し, 線形安定性解析を介して, 亜結晶粒の 2 次元空間パ ターニングをシミュレートすることを試みる。

\section{2. 転位密度テンソル・保存則および権成式}

$2 \cdot 1$ 転位密度テンソル 転位密度には, 前報(5)で定義 した次のような粒子描像転位密度テンソルを用いる。

$$
\begin{aligned}
& \alpha^{m}=s \otimes\left\{\alpha_{e}^{m}(s \times m)+\alpha_{s}^{m} s\right\} \\
& \alpha^{i}=s \otimes\left\{\alpha_{e}^{i}(s \times m)+\alpha_{s}^{i} s\right\} \ldots
\end{aligned}
$$

ここで, $\alpha_{e}^{m}, \alpha_{e}^{i}$ は可動および不動転位の刃状成分, $\alpha_{s}^{m}, \alpha_{s}^{i}$ は らせん成分であり,これらをまとめて

$$
\alpha^{m}, \alpha^{i} \rightarrow \alpha^{[n]}(n=m, i) .
$$

のように記すことにする．また $s$ および $\boldsymbol{m}$ は結晶基底である.

$2 \cdot 2$ 保存則と欈成式転位密度の保存則に対する局所 形として次式のような転位密度の釣合い方程式が得られる。

$$
\partial \alpha^{[n]} / \partial t=-\operatorname{div} \stackrel{(3)}{M}^{[n]}+G^{[n]}
$$

ここで, $\stackrel{M}{M}^{[n]}$ は転位密度流束, また $\boldsymbol{G}^{[n]}$ は湧き出し項であり，

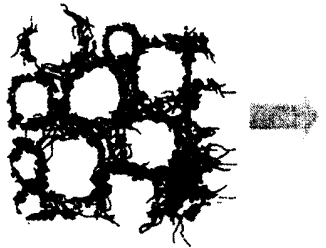

(a) Cell

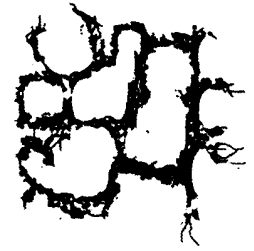

(b) Subgrain
転位の発生項 $\boldsymbol{G}_{p}^{[n]}$ および反応項 $\boldsymbol{G}_{r}^{[n]}$ に分離される.すなわち，

$$
G^{[n]}=G_{p}^{[n]}+G_{r}^{[n]}, \quad \sum_{n} G_{r}^{[n]}=0
$$

である. 一方， $\stackrel{(3)}{[}^{[n]} や \boldsymbol{G}_{r}^{[n]}$ の構成式は前報 ${ }^{(5)}$ と同様に，転位 拡散のエントロピー流束を導入したエントロピー不等式から Clausius-Duhem の不等式を導き, 最大散逸速度の原理を適用 することによって導出される.

\section{3. 反応一拡散方程式}

諸構成式を転位密度の釣合い式(4)に代入し，さらにセル構 造が主すべり面上で等方性を有し，転位密度の刃状成分およ びらせん成分の大きさがともに等しいと仮定すると，両成分 を合成した連立反応 - 拡散方程式が次のように得られる.

$$
\begin{aligned}
& \alpha_{, t}^{m}=D^{m} \nabla^{2} \alpha^{m}+K_{1} \alpha^{i}-K_{2} \alpha^{m} \alpha^{i} \\
& -K_{3} \alpha^{m} \alpha^{i^{2}}-K_{4} \alpha^{m} \alpha^{i^{3}}-L_{1} \alpha^{m} \alpha^{i} \\
& \alpha_{, t}^{i}=D^{i} \nabla^{2} \alpha^{i}+B_{0}-B_{1} \alpha^{i}-B_{2} \alpha^{i^{2}}-K_{1} \alpha^{i}+K_{2} \alpha^{m} \alpha^{i} \\
& +K_{3} \alpha^{m} \alpha^{i^{2}}+K_{4} \alpha^{m} \alpha^{i^{3}}-L_{1} \alpha^{m} \alpha^{i}
\end{aligned}
$$

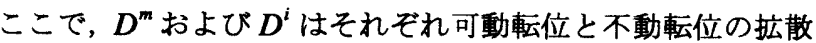
係数である. 式(6)および式(7)において可動転位と不動転位の 反応・生成・消滅・回復は, 図 2 に示すモデルに従うものと する. 図 2(a)は可動転位と不動転位の反応を表している， $K_{1}$ はしきい值を超える負荷応力の作用により，林立転位等の障 害物に捕われていた不動転位が可動化する過程を表している. $K_{2} \sim K_{4}$ はあらかじめトラップされている不動転位に次々と 可動転位が堆積していく過程を表している.ここで 5 次以上 の堆積項は，数值解析結果への影響が小さいため，本報では 4 次項までを採用している. 図 2(b), (c)は転位の生成および 消滅を表している， $B_{0}$ は不動転位の線形生成率， $B_{1}$ は熱拉 散による点欠陥の移動に伴う刃状転位の上昇運動およびらせ ん転位の交差すべりを表している． $B_{2}$ は熱拡散によるダイポ ールの対消滅を表している，図 2(d)の ムは本報で新たに導 入した動的回復を表す項であり，トラップされた不動転位と 異符号の可動転位が反応して対消减することを表している. これは，線形硬化段階でセル壁に転位が高密度に堆積するこ とにより, 可動転位と出会う確率が増すことに起因している.

\section{4. 数值シミュレーション結果およひ検討}

4.1 線形安定性解析 式(6)および式(7)に線形安定性解 析を施せば, 忘力影響係数 $K_{1}$ と抬散係数比 $d^{*} \equiv D^{i} / D^{m}$ の関 係が図 3 のような不安定線図として表現される.これを見る と, Turing 不安定が起こる領域 II の面積が前報 ${ }^{(4)}\left(L_{1}=0\right)$ の 面積と比較して減少しており, 低い応力值では Turing 分岐が

Fig.1 Schematic dislocation cell structure and subgrain

$〔$ No.02-2〕日本機械学会第 15 回計算力学講演会講演論文集〔2002-11.2 4 $\cdot$ 鹿児島市 
起こりにくい傾向を示している.これは，動的回復段階の応 力值が線形硬化段階より大きいことにも符号する.

$4 \cdot 2$ 拡散係数比依存性 反応-拡散方程式(6)，(7)を差 分近似し, 不動転位密度の初期值に基準值 $\alpha_{0}^{i}$ の約 10\%のゆら ぎを与え, 周期境界条件を適用して， 1 辺 $10 \mu \mathrm{m}$ の正方形領 域を対象として数值解析を行う。動的回復が起こり始めるの はセル構造が形成された後であるから，まずセルパターンの みを形成させる. 式(6)，(7)で $L_{1}=0$ とおいて回復項を除き， 前報 ${ }^{(4)}$ で検討した材料定数: $K_{1}=280 / \mathrm{s}, K_{2}=0.09 \mu \mathrm{m}^{2} / \mathrm{s}$, $K_{3}=1.3 \mu \mathrm{m}^{4} / \mathrm{ks}, \quad K_{4}=0.45 \mu \mathrm{m}^{6} / \mathrm{Ms}, \quad B_{0}=70 \mu \mathrm{m}^{2} / \mathrm{s}, B_{1}=4.0 / \mathrm{Gs}$, $B_{2}=700 \mathrm{pm}^{2} / \mathrm{s}, \quad D^{m}=7.0 \mu \mathrm{m}^{2} / \mathrm{s}, \quad D^{i}=0.68 \mu \mathrm{m}^{2} / \mathrm{s}, \quad \alpha_{0}^{m}=150 / \mu \mathrm{m}^{2}$, $\alpha_{0}^{i}=1000 / \mu \mathrm{m}^{2}$ を用いて数值解析を行う. 本条件下で時間ステ ップ $N=1.0 \times 10^{5}$ まで計算した結果を図 4(a)〜(e)に示す.これ らは前報の結果とほほ同様である。

さらに，セル形成が完了した図 4(e)の状態から回復項の倸 数を $L_{1}=0.20 \mu \mathrm{m}^{2} / \mathrm{s}$ に変更して式(6), (7)に導入し, $N=1.5 \times 10^{5}$ まで計算を進める，その際，図 3 の領域 II で拡散係数比を変 化させると，図 3(a)〜(d)のようなパターンが現れる.いずれ の場合もセル内部の転位密度 $\alpha_{c}$ は比較的低く $\alpha_{c}=20 / \mu \mathrm{m}^{2}$ で ある，平衡から遠い非平衡状態である図 3(a)では，セル壁内 転位密度 $\alpha_{w}=200 / \mu^{2}$, 解析領域内平均転位密度 $\bar{\alpha}=100 / \mu \mathrm{m}^{2}$, すなわち $\alpha_{w} / \bar{\alpha} \approx 2$ となり, セル壁内と全体平均の転位密度差 は比較的小さく，セル壁内に小さい空孔が多数見られる。ま た，セル形状は回復項 ムを考慮しない場合と同様に丸みをお び，セル壁は厚いままである.図 3(b)では $\alpha_{w}=2600 / \mu \mathrm{m}^{2}$,

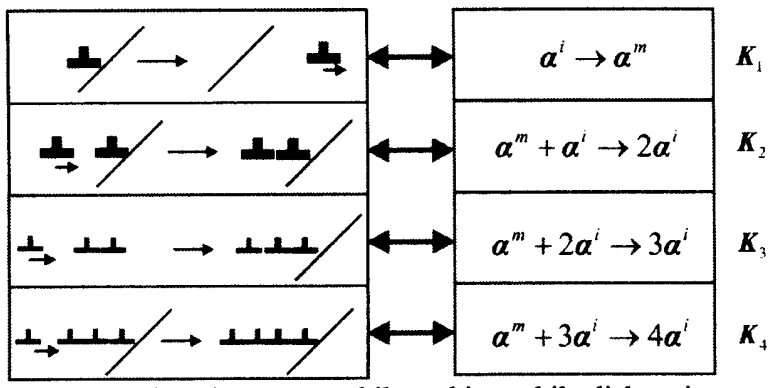

(a) Reactions between mobile and immobile dislocations

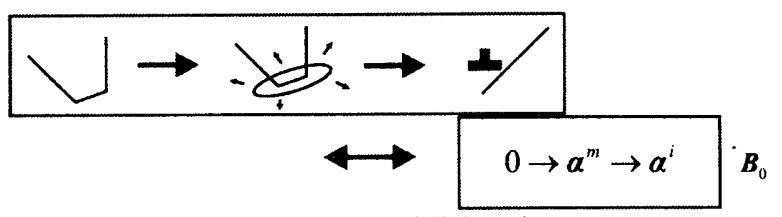

(b) Production of dislocations

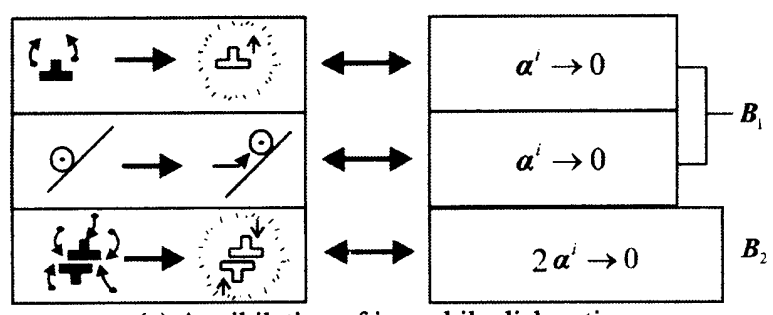

(c) Annihilation of immobile dislocations

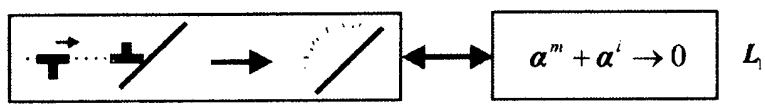

(d) Pair annihilation of mobile and immobile dislocations

Fig.2 Reaction, production, annihilation and recovery models of dislocations

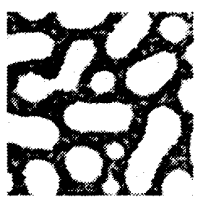

(a) $d^{*}=1.0 \times 10^{-4}$

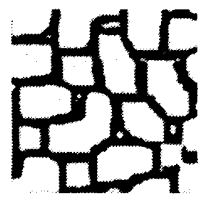

(b) $5.0 \times 10^{-2}$

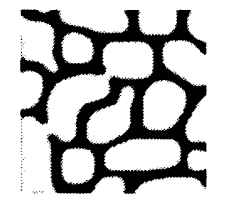

(c) $5.7 \times 10^{-2}$
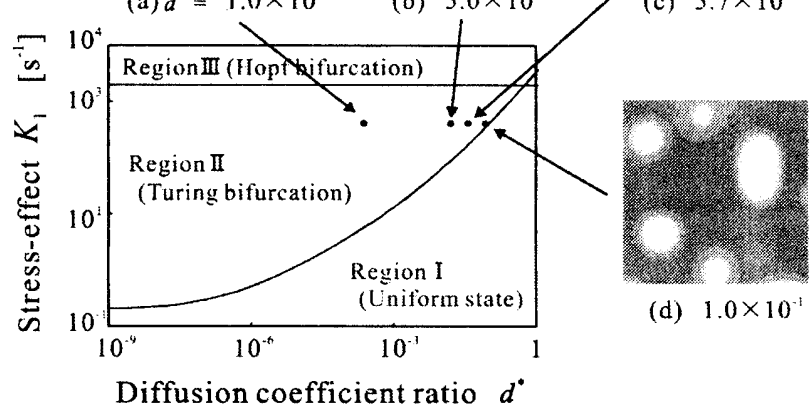

(d) $1.0 \times 10^{\prime}$

Fig.3 Instability diagram

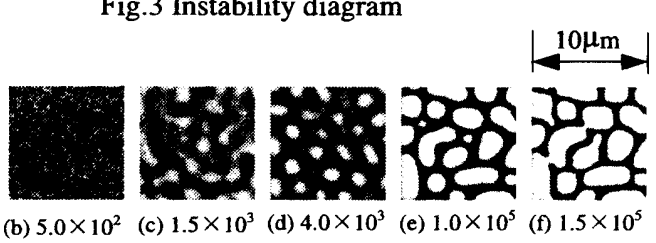

Fig. 4 Dislocation patterns for time step

$\bar{\alpha}=1000 / \mu \mathrm{m}^{2}, \quad \alpha_{w} / \bar{\alpha} \approx 3$ となるとともに, セル壁の厚さが薄 くなる．また，セル形状は円状から四角状になり，セル壁内 の空孔数は減少する. 次に, 図 3(c)のように Turing 曲線から 横軸負の方向へ約 5\%ほど離れた状態まで非平衡度を下げる と， $\alpha_{w}$ およ゙ $\bar{\alpha}$ の值は図 3(b)の場合とほぼ同一で, セル形状 は再び丸みをおびるようになり，セル壁の薄さが保持された ままセル寸法は大きくなる．ただし，セル壁内に見られた空 孔は消滅する。これらの傾向から, 図 3(c) はセルが亜結晶粒 へ遷移したものであるとみなせる.ささらに，拡散係数比を増 加させた図 3(d)では空間均一状態に極めて近くなる.

$4 \cdot 3$ 亜結晶粒の形成過程 前節の検討より, 拡散係数 比 $d^{*}$ はセル形成前後で同一とするのが望ましいといえる. そ こで, 図 3(c)を採用して初期から定常状態までの過程を時系 列に並べれば図 4(a)〜(f)のようになる. 以上より, 係数 $L_{1}$ を もつ回復項は，セル壁の厚さを薄くし，セル同士を合体させ てセルサイズを増加させ，セル形状の丸みを减少させて亜結 晶粒に遷移させる働きをもつことがわかる，なお，計算の初 期から予め動的回復項を導入して数值解析を行うと, 細かい 点状および線状パターンとなり, セルも亜結晶粒も形成され ないという結果を得ている。

\section{5. 結 言}

（1）不安定線図における Turing 曲線から横軸負の方向一約 5\%ほど離れた拡散保数比を採用すると, セル壁内と領域 全体の平均転位密度差ならびにセルサイズは増大し, セ ル形状の丸みが减少して覀結晶粒パターンが得られる。

（2）セル壁にトラップされた不動転位に異符号の可動転位が 反応して対消滅することをモデル化した回復項は，セル 形状を亜結晶粒形状へ遷移させる働きをもつ.

\section{文 献}

（1）㐘池・森田・志澤，第 51 回理論応力講論, (2002), 449.

(2) 生司・毛利, 機構論, No.01-16, (2001), 573.

(3) 長谷部, 機構論, No.01-10, (2001), 85.

(4) 松下. 藤本・志澤, 機構論 (M\&M 2002), 講演番号 109.

（5）森田・菊池・志澤, 機構論, No.01-16, (2001), 569. 